\title{
TOTAL IgE DETECTION IN PAIRED CEREBROSPINAL FLUID AND SERUM SAMPLES FROM PATIENTS WITH NEUROCYSTICERCOSIS(1)
}

\author{
Ednéia Casagranda BUENO(2, 3), Adelaide José VAZ(3), Luís dos Ramos MACHADO(4) \& José Antônio LIVRAMENTO(4)
}

\begin{abstract}
SUMMARY
Neurocysticercosis (NC), the presence of Taenia solium metacestodes in tissues, is the most frequent and severe parasitic infection of the central nervous system. We investigated the presence of total IgE by an automated chemiluminescence assay in 53 paired cerebrospinal fluid (CSF) and serum samples from patients with $\mathrm{NC} \mathrm{(P)} \mathrm{and} \mathrm{in} 40 \mathrm{CSF}$ samples from individuals with other neurological disorders as the control group $(\mathrm{C})$. Total IgE concentration ranged from 1.2 to $6.6 \mathrm{IU} / \mathrm{ml}(\mathrm{mean}=1.4 \mathrm{IU} / \mathrm{ml}$, standard deviation-sd $=$ $1.1 \mathrm{IU} / \mathrm{ml})$ in $28.3 \%$ of CSF samples from the P group, a value significantly higher than for the $\mathrm{C}$ group $(\leq 1.0 \mathrm{IU} / \mathrm{ml})$. The serum samples from the P group showed concentrations ranging from 1.0 to $2330.0 \mathrm{IU} / \mathrm{ml}($ mean $=224.1 \mathrm{IU} / \mathrm{ml}, \mathrm{sd}=452.1 \mathrm{IU} / \mathrm{ml})$, which were higher than the normal value cited by the manufacturer $(<100.0 \mathrm{IU} / \mathrm{ml})$ in $32.1 \%$ of the samples. A significant difference was observed in CSF samples from the $\mathrm{P}$ and $\mathrm{C}$ groups $(\mathrm{p}=0.005)$ and in serum samples from the $\mathrm{P}$ group compared to the normal value $(\mathrm{p}=0.005)$, with sera showing more frequent abnormal results.
\end{abstract}

KEYWORDS: Cysticercosis; IgE; Serum; CSF.

\section{INTRODUCTION}

Neurocysticercosis (NC), the presence of Taenia solium metacestodes in tissues, is the most frequent and severe parasitic infection of the central nervous system. Its distribution is universal, being frequent in developing countries in Latin America, Africa, Asia and India ${ }^{1,9,16,18,20}$, and with cases reported in the United States due to the immigration of individuals coming from endemic areas ${ }^{17}$.

The diagnosis of NC is based on clinical, epidemic and laboratory data (neuroimaging and immunological methods). Since clinical diagnosis is hindered by the nonspecific and polymorphic symptomatology of $\mathrm{NC}$, the detection of anti-T. solium antibodies in cerebrospinal fluid (CSF) represents an important diagnostic factor $^{2,8,9,13,22,23}$.

Most of the antibodies found in CSF are intrathecally synthesized, with a smaller proportion coming from peripheral blood by blood-brain barrier rupture ${ }^{7}$. Some authors have reported specific IgG, IgM, IgA and $\mathrm{IgE}$ antibodies in $\mathrm{CSF}$ and/or serum from patients with $\mathrm{NC}$, without a correlation between antibody class and clinical aspect of the disease $e^{3,5,6,12}$. In parasitic infections, including the teniasis-cysticercosis complex, the level of total IgE can be high, many times without the identification of the specificity of the antibody ${ }^{14,19}$.
The objective of the present study was to investigate the total IgE antibodies in CSF and serum samples from patients with NC by a chemiluminescence assay.

\section{MATERIAL AND METHODS}

We studied 53 paired CSF and serum samples from patients with NC (P) selected according to the General Protocol of NC Investigation followed at the Center of Neurological Investigations, University Hospital, Faculty of Medicine of the University of São Paulo. The study was approved by the Ethics Committee for Analysis of Research Projects, Clinical Management of UHFMUSP, 072/97, in agreement with Resolution 196/96 of the National Council of Health, Ministry of Health, Brasilia, Brazil. The patients' age ranged from 15 to 72 years [mean, 40 years; standard deviation (sd), 13 years].

As a control group (C) we studied $40 \mathrm{CSF}$ samples from individuals with other non-NC neurological disorders in order to evaluate the method of CSF sample analysis. For serum samples we considered the normal value to be $100.0 \mathrm{IU} / \mathrm{ml}$, as cited by the manufacturer.

We detected total IgE using an automated chemiluminescence assay (IMMULITE Total IgE, DPC Diagnostic Products Corporation, Los Angeles, USA).

\footnotetext{
(1) Part of this work was presented as the Master's Thesis of E. C. Bueno (USP, 1999). Financial support: FAPESP (96-7679-1).

(2) E. C. Bueno was supported by a fellowship from CAPES

(3) Laboratory of Clinical Immunology, Faculty of Pharmaceutical Sciences, University of São Paulo, São Paulo, SP, Brazil

(4) Faculty of Medicine, University of São Paulo, São Paulo, SP, Brazil

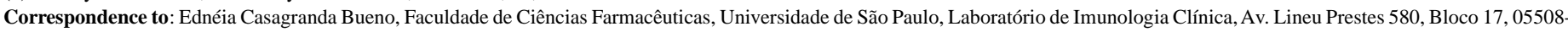
900 São Paulo, SP, Brasil. Phone: 55-11-8183638. Fax: 55-11-8132197. E-mail: ecbueno@usp.br
} 
In the test, an antibody sandwich complex is formed between $\operatorname{IgE}$ of sample, solid-phase (polystirene bead coated with a polyclonal antibody specific for IgE) and conjugate (alkaline phosphatase-conjugated IgE monoclonal antibody). Unbound enzyme conjugated is removed by a centrifugal wash, after which chemiluminescent substrate (phosphate ester of adamantyl dioxetane) is added. The chemiluminescent substrate undergoes hydrolysis in the presence alkaline phosphatase to yield an unstable intermediate, that results in the sustained emission of light. The bound complex (photon output) as measured by the luminometer, and is proportional to the concentration of total $\operatorname{IgE}$ in the sample, calculated starting from standard curve.

The mean and standard deviations were calculated for each group and the data analyzed by the Mann-Whitney test (Software INSTAT).

\section{RESULTS}

Total IgE, reported as IU/ml, for the CSF and serum samples analyzed by chemiluminescence are presented in Figure 1.

In $28.3 \%$ of CSF samples from the P group, total $\mathrm{IgE}$ concentration ranged from 1.2 to $6.6 \mathrm{IU} / \mathrm{ml}$ [mean, $1.4 \mathrm{IU} / \mathrm{ml}$; sd, $1.1 \mathrm{IU} / \mathrm{ml}$ ], values significantly higher than those detected in the $\mathrm{C}$ group $(\mathrm{p}=0.005)$. The
$40 \mathrm{CSF}$ samples from the $\mathrm{C}$ group showed $\mathrm{IgE}$ levels lower $1.0 \mathrm{IU} / \mathrm{ml}$ (Figure 1).

In $32.1 \%$ of serum samples from the P group, total IgE concentrations were higher than normal (up to $100.0 \mathrm{IU} / \mathrm{ml}$ ). The concentrations obtained for all serum samples ranged from 1.0 to $2330.0 \mathrm{IU} / \mathrm{ml}$ (mean, 224.1 IU/ $\mathrm{ml}$; sd, $452.1 \mathrm{IU} / \mathrm{ml}$ ) (Figure 1).

The results showed $15.1 \%$ of paired CSF and serum samples with total IgE concentration higher than normal values and/or controls. CSF IgE levels differed significantly between the $P$ and $C$ groups $(p=0.005)$, and serum IgE levels differed significantly between the $\mathrm{P}$ group and normal values $(\mathrm{p}=0.005)$.

\section{DISCUSSION}

The biological parasite-host interactions involved in $\mathrm{NC}$ are complex because of the different evolutionary stages of the parasite and of the individual variations in the response of the host ${ }^{17}$. The mechanisms of the humoral immune response have been studied especially during the active phase of the disease, and several authors have detected IgG antibodies in $\mathrm{CSF}$ and/or serum from patients with $\mathrm{NC}^{3,6,7,8}$. There are only few reports about the immune response in different evolutionary stages of $\mathrm{NC}^{4}$.

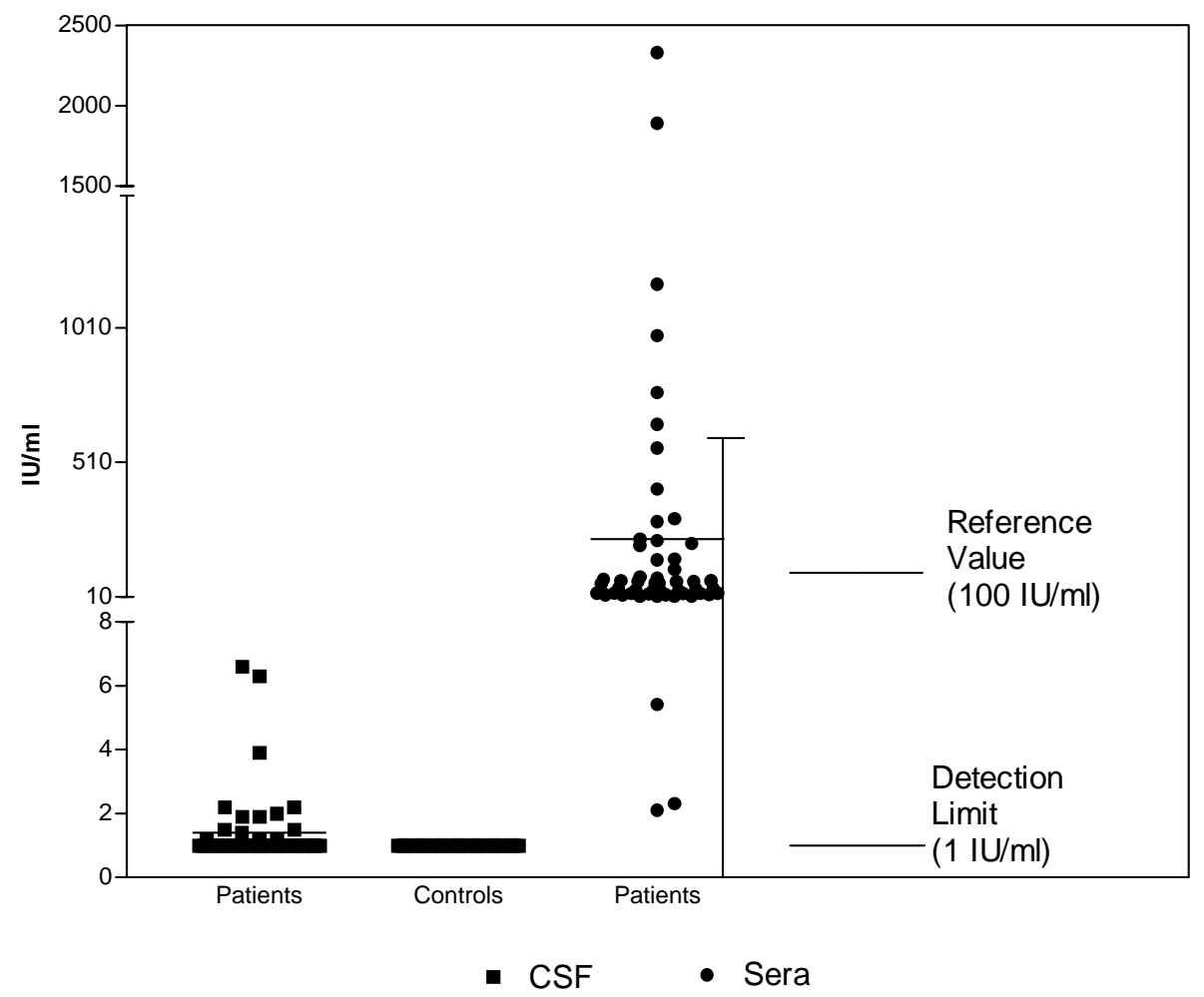

Fig. 1 - Total IgE levels (IU/ml) determined by chemiluminescence in 53 CSF and serum samples from patients with neurocysticercosis and in 40 CSF samples 
The level of total $\mathrm{IgE}$ has been determined by different methods in parasitic infections, including $\mathrm{NC}^{10,14,19,21}$. OSTROSKY-ZEICHNER et $a l .{ }^{15}$, reported that total $\mathrm{IgE}$ levels determined by radioimmunoassay were higher than control in 59\% of CSF samples from patients with NC. In contrast to these findings, we observed only $28.3 \%$ CSF samples from the $\mathrm{P}$ group with higher total $\mathrm{IgE}$ concentration than in the $\mathrm{C}$ group. We observed a mean total IgE concentration of $1.4 \mathrm{IU} / \mathrm{ml}$ in CSF samples from the P group, similar to the values reported by SPINA-FRANÇA et $a l .^{21}$ and OSTROSKY-ZEICHNER et al. ${ }^{15}$, but different from those reported by GOLDBERG et al. ${ }^{10}(0.44 \mathrm{IU} / \mathrm{ml})$, and MELO et al. ${ }^{14}(0.76$ $\mathrm{IU} / \mathrm{ml})$. The first three groups used radioimmunoassay, and the last one used an immunoenzymatic test with a fluorigenic substrate.

The serum samples showed $224.1 \mathrm{IU} / \mathrm{ml}$ of total $\mathrm{IgE}$, similar to GORODEZKY et al. ${ }^{11}$. These authors detected higher IgE concentrations in $52 \%$ of the serum samples from patients with $\mathrm{NC}$ than in the control group, as opposed to a $32.1 \%$ rate in the present study. Some authors ${ }^{10}$ have reported higher mean concentrations of total $\mathrm{IgE}(516.0 \mathrm{IU} / \mathrm{ml})$ in serum samples from patients with NC than we observed here, while others ${ }^{19}$ reported a lower concentration $(28.6 \mathrm{IU} / \mathrm{ml})$ detected by radioimmunoassay.

Although only 2 (3.8\%) CSF samples and 7 (13.2\%) serum samples showed specific IgE by ELISA (data not shown), the results indicate that the humoral immune response in $\mathrm{NC}$ also involves total $\mathrm{IgE}$ production. The present results confirm the complex parasite-host relationship involved in $\mathrm{NC}$, whose full elucidation requires further investigation.

\section{RESUMO}

\section{Detecção de IgE total em amostras pareadas de líquido cefalorraquiano e soro de pacientes com neurocisticercose}

Neurocisticercose (NC), causada pela presença da forma larvária de Taenia solium em tecidos, é a mais frequente e grave infecção parasitária que acomete o sistema nervoso central. Nós investigamos a presença de IgE total por quimiluminescência em 53 amostras pareadas de líquido cefalorraquiano (LCR) e soro de pacientes com NC (P) e 40 amostras de LCR de indivíduos portadores de outras desordens neurológicas como grupo controle (C). A detecção de IgE total mostrou 28,3\% das amostras de LCR do grupo P com concentrações entre $1,2 \mathrm{UI} / \mathrm{ml}$ e $6,6 \mathrm{UI} / \mathrm{ml}$ (média $=1,4 \mathrm{UI} / \mathrm{ml}$, desvio padrão-sd $=1,1 \mathrm{UI} / \mathrm{ml}$ ), maiores que o grupo $\mathrm{C}(\leq 1,0 \mathrm{UI} / \mathrm{ml})$. As amostras de soro do grupo P mostraram concentrações entre $1,0 \mathrm{UI} / \mathrm{ml}$ e $2330,0 \mathrm{UI} / \mathrm{ml}$ (média $=224.1 \mathrm{UI} / \mathrm{ml}$, $\mathrm{sd}=452,1 \mathrm{UI} /$ $\mathrm{ml})$, e $32,1 \%$ das amostras apresentaram valores maiores que o valor normal citado pelo fabricante $(<100,0 \mathrm{UI} / \mathrm{ml})$. Diferença significativa foi encontrada entre as amostras de LCR dos grupos P e C $(p=0,005)$ e entre as amostras de soro do grupo $\mathrm{P}$ e valor de referência $(\mathrm{p}=0,005)$, sendo os resultados dos soros mais frequentemente alterados.

\section{ACKNOWLEDGMENTS}

We are indebted to DPC - Medlab, Produtos Médicos Laboratórios Ltda. for providing kits for IgE detection, and to Victor Debas from BioCiência/Lavoisier Laboratory for technical assistance with the tests.

\section{REFERENCES}

1. AGAPEJEV, S. - Epidemiology of neurocysticercosis in Brazil. Rev. Inst. Med. trop. S. Paulo, 38: 207-216, 1996

2. ANDRADE, A.P.; VAZ, A.J.; NAKAMURA, P.M. et al. - Immunoperoxidase for the detection of antibodies in cerebrospinal fluid in neurocysticercosis: use of Cysticercus cellulosae and Cysticercus longicollis particles fixed on microscopy slides. Rev. Inst. Med. trop. S. Paulo, 38: 259-263, 1996.

3. BONAMETTI, A.M.; BASILE, M.A.; VAZ, A.J.; BALDY, J.L.S. \& TAKIGUTI, C.K. Índice de positividade da reação imunoenzimática (ELISA) para cisticercose no líquido cefalorraquidiano (LCR) e no soro de pacientes com epilepsia. Rev. Inst. Med. trop. S. Paulo, 34: 451-458, 1992.

4. BUENO, E.C.; VAZ, A.J.; MACHADO, L.R.; LIVRAMENTO, J.A. \& MIELLE, S.R. Specific Taenia crassiceps and Taenia solium antigenic peptides for neurocysticercosis immunodiagnosis using serum samples. J. clin. Microbiol., 38: 146-151, 2000.

5. CORREA, D.; DALMA, D.; ESPINOZA, B. et al. - Heterogeneity of humoral immune components in human cysticercosis. J. Parasit., 71: 535-541, 1985

6. ESPINOZA, B.; PALACIOS, G.R.; TOVAR, A. et al. - Characterization by enzymelinked immunosorbent assay of the humoral immune response in patients with neurocysticercosis and its application in immunodiagnosis. J. clin. Microbiol., 24: 536-541, 1986.

7. ESTANOL, B.; JUÁREZ, H.; IRIGOYEN, M.C.; GONZÁLEZ-BARRANCO, D. \& CORONA, T. - Humoral immune response in patients with cerebral parenchymal cysticercosis treated with praziquantel. J. Neurol. Neurosurg. Psyquiat., 52: 254$257,1989$.

8. FERREIRA, A.P.; VAZ, A.J.; NAKAMURA, P.M. et al. - Hemagglutination test for the diagnosis of human neurocysticercosis: development of a stable reagent using homologous and heterologous antigens. Rev. Inst. Med. trop. S. Paulo, 39: 29-33, 1997.

9. GARCIA, E.; ORDONEZ, G. \& SOTELO, J. - Antigens from Taenia crassiceps used in complement fixation, enzyme-linked immunosorbent assay, and western blot (immunoblot) for diagnosis of neurocysticercosis. J. clin. Microbiol., 33: 3324-3325, 1995.

10. GOLDBERG, A.S.; HEINER, D.C.; FIREMARK, H.M. \& GOLDBERG, M.A. Cerebrospinal fluid IgE and the diagnosis of cerebrospinal cysticercosis. Bull. Los Angeles neurol. Soc., 46: 21-25, 1981.

11. GORODEZKY, C.; DIAZ, M.L.; ESCOBAR-GUTIERREZ, A. \& FLISSER, A. - IgE concentration in sera of patients with neurocysticercosis. Arch. invest. méd. (Méx.), 18: $225-227,1987$.

12. GROGL, M.; ESTRADA, J.J.; MACDONALD, G. \& KUHN, R.E. - Antigen-antibody analysis in neurocysticercosis. J. Parasit., 71: 433-442, 1985.

13. LARRALDE, C.; SOTELO, J.; MONTOYA, R.M. et al. - Immunodiagnosis of human cysticercosis in cerebrospinal fluid. Arch. Path. Lab. Med., 114: 926-928, 1990.

14. MELO, C.S.; VAZ, A.J.; NAKAMURA, P.M.; SILVA, M.V. \& MACHADO, A.B.B. Human neurocysticercosis. IgE in cerebrospinal fluid. Arq. Neuropsiquiat. (S. Paulo), 55: 8-11, 1997.

15. OSTROSKY-ZEICHNER, L.; GARCIA-MENDOZA, E.; RIOS, C. \& SOTELO, J. Humoral and cellular immune response within the subarachnoid space of patients with neurocysticercosis. Arch. med. Res., 27: 513-517, 1996.

16. SARTI, E.; FLISSER, A.; SCHANTZ, P.M. et al. - Development and evaluation of a health education intervention against Taenia solium in a rural community in Mexico. Amer. J. trop. Med. Hyg., 56: 127-132, 1997. 
BUENO, E.C.; VAZ, A.J.; MACHADO, L. dos R. \& LIVRAMENTO, J.A. - Total IgE detection in paired cerebrospinal fluid and serum samples from patients with neurocysticercosis. Rev. Inst. Med. trop. S. Paulo, 42(2): 67-70, 2000.

17. SCHANTZ, P.M.; MOORE, A.C.; MUÑOZ, J.L. et al. - Neurocysticercosis in an orthodox jewish community in New York City. New Engl. J. Med., 327: 692-695, 1992.

18. SHASHA, W. \& PAMMENTER, M.D. - Sero-epidemiological studies of cysticercosis in school children from two rural areas of Transkei, South Africa. Ann. trop. Med. Parasit., 85: 349-355, 1991.

19. SHORT, J.A.; HEINER, D.C.; HSIAO, R.L. \& ANDERSEN, F.L. - Immunoglobulin E and G4 antibodies in cysticercosis. J. clin. Microbiol., 28: 1635-1639, 1990.

20. SINGH, G. - Neurocysticercosis in South-Central America and the Indian subcontinent. Arq. Neuropsiquiat. (S. Paulo), 55: 349-356, 1997.
21. SPINA-FRANÇA, A.; KLEINE, T.O.; LIVRAMENTO, J.A. \& MACHADO, L.R. - IgE determination in cerebrospinal fluid and serum of patients with neurocysticercosis by a modified enzyme immunoassay. Protides biol. Fluids, 34: 657-660, 1986

22. VAZ, A.J.; NAKAMURA, P.M.; BARRETO, C.C. et al. - Immunodiagnosis of human neurocysticercosis: use of heterologous antigenic particles (Cysticercus longicollis) in indirect immunofluorescence test. Serodiag. Immunother. Infect. Dis., 8: 157161, 1997.

23. VAZ, A.J.; NUNES, C.M.; PIAZZA, R.M.F. et al. - Immunoblot with cerebrospinal fluid from patients with neurocysticercosis using antigen from cysticerci of Taenia solium and Taenia crassiceps. Amer. J. trop. Med. Hyg., 57: 354-357, 1997.

Received: 19 November 1999

Accepted: 16 March 2000 